\title{
Enterprise Architecture Planning of North Sulawesi Tourism Information System as a Website Container of the Tourism Office using the Zachman Framework
}

\author{
Yonatan Parassa \\ Manado State Polytechnic
}

\author{
Mex U. Pesik \\ Manado State Polytechnic
}

\author{
Toban T. Pairunan Alma K. Pongtuluran \\ Manado State Polytechnic Manado State Polytechnic
}

\begin{abstract}
The tourism sector in North Sulawesi Province continues to grow, it can be seen by the soaring growth of tourist visits. It is unfortunate that these developments have not been supported by reliable tourism information, while now it is the industrial era 4.0.
\end{abstract}

In 2018, of the 16 Tourism Offices, only 3 tourism offices in North Sulawesi Province had a website, while the tourism office was part of the government that played an important role in promoting tourism for the welfare of the community.

The purpose of this research is to design a tourism information system in North Sulawesi as a website container for tourism office.

Enterprise Architecture Planning is a method used to design tourism information systems.

The results of this study are the design of the North Sulawesi tourism information system as a website container for the tourism office using the Zachman Framework.

\section{Keywords}

Tourism Information systems, North Sulawesi, Website Container

\section{INTRODUCTION}

North Sulawesi Province is a tourist destination and included in the international tourism destination [1]. Seen by the soaring growth of tourist visits [2]. The increase in tourist arrivals is one source of foreign exchange for the Province of North Sulawesi. Foreign exchange earnings through the field of tourism is a contribution to development [3]. In 2009 Tourism was the third largest foreign exchange earner for the country of Indonesia [4]. Minister of National Development Planning Bambang Brodjonegoro during the Seminar and National Dialogue on Millennial Creative Economy in the Industrial Revolution Era 4.0. "Tourism is the biggest source because Indonesia is an important country in international tourism" [5]. Tourism is a sector that has a huge impact on the economy [6].

It is unfortunate that the development of tourism in North Sulawesi Province has not been supported by qualified information, while now it is the industrial era 4.0. Tourism information that can be accessed via the internet has not been supplied much by the tourism office. Based on the observation of the Research Team, in 2018 out of 16 Dinas, only 3 tourism offices in North Sulawesi Province have a website, while the tourism department is part of the government which plays an important role in promoting tourism for the welfare of the community.

On the other hand the Central Government through the ministry of tourism utilizes digital technology for promotion.
70 percent of promotions use digital [7].

The information system that functions as a website container for the tourism office is one solution so that all tourism services in the province of North Sulawesi can convey tourism information through the internet that can be accessed by tourists or potential tourists.

This information system can be used by tourism offices that do not yet or also offices that already have a website. So that all tourism offices can convey information through the internet through one door.

The system design is a thing that greatly influences the quality of the software. Zachman framework is a capable method for designing software that refers to Enterprise Architecture Planning (EAP).

This research applies the Zachman Framework method in the design of North Sulawesi tourism information systems to get quality that ensures software is built according to the rules.

The results of this study are the implementation of the zachman framework in the design of the North Sulawesi Tourism Information System as a tourism office website container is expected to provide a solution for tourism agencies that do not yet have a website.

\section{LITERATUR REVIEW}

EAP according to Spewak in Kurniawan explained about various architectures, namely data, applications and technology [8].

Framework is an EPA function that classifies information through logical structures [9]. The Zachman framework is used to align organizational architecture and information technology [10].

Good long-term planning must be had when building information systems. Information system development plan is an investment of an organization as outlined in the master plan document [11]

The result of collecting and processing data to valuable information that comes from an integrated environment of the internet is an information system [12]. One component that influences the success of an organization is the information system [13].

Some previous research with a focus on the importance of information systems and enterprise architecture, [10], [14], $[15,[16]$.

\section{RESEARCH METHODS}

This research uses the Zachman framework to design the system. In general, the Zachman method consists of columns and rows to produce information systems. The column 
consists of what, how, where, who, when and why. The line consists of Planner, owner, designer, builder, sub-contractor and functioning enterprise [17].

Data collection methods with documentation, observation and interview techniques [18].

\section{RESULT AND DISCUSSION}

Use the Zachman framework to design the North Sulawesi

Table 1. Zachman Matrix of Information system

\begin{tabular}{|c|c|c|c|c|c|c|}
\hline $\begin{array}{l}\text { ABSTRACTION / } \\
\text { PERSECTIVE }\end{array}$ & $\begin{array}{l}\text { DATA / } \\
\text { What }\end{array}$ & $\begin{array}{c}\text { FUNCTION / } \\
\text { How }\end{array}$ & $\begin{array}{l}\text { NETWORK / } \\
\text { Where }\end{array}$ & PEOPLE / Who & TIME / When & $\begin{array}{c}\text { MOTIVATION / } \\
\text { Why }\end{array}$ \\
\hline $\begin{array}{c}\text { SCOPE } \\
\text { (CONTEXTUAL) } \\
\text { / Planner }\end{array}$ & $\begin{array}{l}\text { Tourism } \\
\text { Office data }\end{array}$ & $\begin{array}{l}\text { The work } \\
\text { program } \\
\text { reporting } \\
\text { process }\end{array}$ & Tourism Office & $\begin{array}{l}\text { Administrator, } \\
\text { operator Tourism } \\
\text { office }\end{array}$ & $\begin{array}{l}\text { Office Data } \\
\text { Input : Work } \\
\text { Program, } \\
\text { socialization }\end{array}$ & $\begin{array}{l}\text { Vision, Mission } \\
\text { tourism office }\end{array}$ \\
\hline $\begin{array}{c}\text { BUSINESS } \\
\text { MODEL } \\
\text { (CONCEPTUAL) } \\
\text { / Owner }\end{array}$ & $\begin{array}{l}\text { Use case } \\
\text { system }\end{array}$ & activity diagram & $\begin{array}{c}\text { Information } \\
\text { System } \\
\text { Network Design }\end{array}$ & $\begin{array}{c}\text { Designer, } \\
\text { administrator, } \\
\text { operator }\end{array}$ & $\begin{array}{c}\text { Schedule } \\
\text { information } \\
\text { system project }\end{array}$ & $\begin{array}{l}\text { the reason for the } \\
\text { procurement of } \\
\text { information } \\
\text { systems }\end{array}$ \\
\hline $\begin{array}{c}\text { SYSTEM } \\
\text { MODEL } \\
\text { (LOGICAL) / } \\
\text { Designer }\end{array}$ & ER Diagram & $\begin{array}{l}\text { sequence, } \\
\text { detailed use } \\
\text { case }\end{array}$ & $\begin{array}{l}\text { network design } \\
\text { proposal }\end{array}$ & $\begin{array}{c}\text { interface } \\
\text { application design }\end{array}$ & $\begin{array}{l}\text { detail system } \\
\text { schedule }\end{array}$ & $\begin{array}{l}\text { rules in making } \\
\text { models }\end{array}$ \\
\hline $\begin{array}{c}\text { TECHNOLOGY } \\
\text { MODEL } \\
\text { (PHYSICAL) / } \\
\text { Builder }\end{array}$ & $\begin{array}{l}\text { Table } \\
\text { Relation }\end{array}$ & $\begin{array}{c}\text { application } \\
\text { usage process }\end{array}$ & $\begin{array}{l}\text { Location and } \\
\text { technology used }\end{array}$ & $\begin{array}{l}\text { overview of the } \\
\text { application } \\
\text { interface }\end{array}$ & $\begin{array}{c}\text { detailed } \\
\text { application } \\
\text { design schedule }\end{array}$ & $\begin{array}{l}\text { the rules in } \\
\text { making designs }\end{array}$ \\
\hline $\begin{array}{c}\text { DETAIL } \\
\text { REPRESENTATI } \\
\text { ONS (OUT-OF- } \\
\text { CONTENT) / sub } \\
\text { Contractor }\end{array}$ & $\begin{array}{l}\text { entity } \\
\text { creation } \\
\text { algorithm }\end{array}$ & $\begin{array}{l}\text { report process } \\
\text { algorithm }\end{array}$ & $\begin{array}{c}\text { Network } \\
\text { configuration }\end{array}$ & $\begin{array}{l}\text { privilege } \\
\text { algorithm }\end{array}$ & $\begin{array}{l}\text { detailed coding } \\
\text { process } \\
\text { schedule }\end{array}$ & $\begin{array}{l}\text { rules in the coding } \\
\text { process }\end{array}$ \\
\hline $\begin{array}{c}\text { FUNCTIONING } \\
\text { ENTERPRISE }\end{array}$ & $\begin{array}{l}\text { an example } \\
\text { of tourism } \\
\text { office data }\end{array}$ & $\begin{array}{c}\text { sample } \\
\text { transaction data } \\
\text { in the system }\end{array}$ & $\begin{array}{c}\text { network } \\
\text { infrastructure }\end{array}$ & $\begin{array}{l}\text { users who use the } \\
\text { system }\end{array}$ & $\begin{array}{l}\text { time schedule } \\
\text { process, design, } \\
\text { implementation }\end{array}$ & $\begin{array}{c}\text { SOP the system } \\
\text { usage }\end{array}$ \\
\hline
\end{tabular}

\section{CONCLUSION}

The province of North Sulawesi is experiencing a rapid development of tourist visits, but it has not been followed by a supply of qualified information from the tourism offices which can be accessed via the internet considering that most tourists access information via the internet.

The information system that functions as a website container for the tourism offices to be able to provide information so that it can be accessed via the internet is a solution.

Software development must use proven methods to ensure the quality of the software is produced.

\section{ACKNOWLEDGMENTS}

On this occasion, the research team would like to thank the Ministry of Research and Technology of Technology and Higher Education of the Republic of Indonesia for funding this research through the directorate of research and community service in 2019. Also to the Manado State Polytechnic and various parties involved in the research.

God bless us all.
Tourism Information System as a Website Container of the Tourism Offices.

Through the stages of communication and data collection to design information systems, obtained a matrix like the following table: 
Selecting Packages: A Survey. International Journal of Computer Applications, 139(5).

[7] https://www.moneysmart.id/pariwisata-indonesiaditargetkan-jadi-sumber-devisa-tertinggi/, accessed date, September 10, 2019.

[8] Kurniawan, (2011). Enterprise architecture planning information systems at private universities with the Zachman Framework. UNIKOM.

[9] Widodo, A., P., 2010, Enterprise Architecture Model for Government Applications, Journal of the Informatics Society, ISSN: 2086-4930

[10] Zarvić, N., \& Wieringa, R. (2014). An integrated enterprise architecture framework for business-IT alignment. Designing Enterprise Architecture Frameworks: Integrating Business Processes with IT Infrastructure, 63(9)r

[11] Rassameethes, B. (2012). Analysis and integration of Thailand ICT master plan. International Journal of Synergy and Research, 1(2), 77-90

[12] The result of collecting and processing data to valuable information that comes from an integrated environment of the internet is an information system

[13] M. Romi Ismail, "Organizational Culture Impact on Information Systems Success", Computer Science and Software Techniques in 2011, vol. 42, 2011.

[14] Aboaoga, M., Ab Aziz, M. J., \& Ibrahim, M. (2018). Information System Success Framework based on Interpersonal Conflict Factors. International Journal of Electrical and Computer Engineering, 8(5), 3740

[15] Forat Falih Hasan. (2018) A Review Study of Information Systems. International Journal of Computer Applications 179(18):15-19

[16] Nogueira, J. M., Romero, D., Espadas, J., \& Molina, A. (2013). Leveraging the Zachman framework implementation using action-research methodology-a case study: aligning the enterprise architecture and the business goals. Enterprise Information Systems, 7(1), 100-132.

[17] J. A. Zachman. (2011). "The Zachman Framework for Enterprise Architecture." p. 2011,.

[18] Rahardjo, M. (2011). Qualitative research data collection methods. 